\title{
The social and ritual context of horizon astronomical observations at Chankillo
}

\author{
Iván Ghezzi ${ }^{1}$ and Clive L. N. Ruggles ${ }^{2}$ \\ ${ }^{1}$ Pontificia Universidad Católica del Perú, Department of Humanities-Archaeology, \\ Av. Universitaria 1801, Lima 32, Peru \\ email: ighezzi@pucp.edu.pe \\ ${ }^{2}$ School of Archaeology and Ancient History, University of Leicester, \\ Leicester LE1 7RH, United Kingdom \\ email: rug@le.ac.uk
}

\begin{abstract}
The authors have shown previously that, as viewed from an evident observing point to the west, and a plausible observing point to the east, the Thirteen Towers of Chankillo formed an artificial 'toothed' horizon that spanned the annual rising and setting arcs of the sun and provided a means to identify each day in the seasonal year by observing the position of sunrise or sunset against them. The Thirteen Towers thus constitute a unique solar observation device that is still functioning, and a remarkable example of a native form of landscape timekeeping that preceded similar facilities in imperial Cusco by almost two millennia. Yet the social, political, and ritual contexts in which Chankillo's astronomical alignments operated deserve further exploration. In this paper, we present new archaeoastronomical evidence that not only clarifies some aspects of the solar observation device but suggests a wider range of alignments visible from more publicly accessible parts of the ceremonial complex, and also suggests a possible interest in marking lunar alignments as well as solar ones. We also bring together archaeological evidence to suggest that the society that built Chankillo was differentiated. The Thirteen Towers may have served to regulate the calendar, solar and ritual, while the solar cult centred on them may have lent legitimacy and authority to a rising warrior elite through ceremony in an impressive sacred setting that brought society together while reproducing its growing inequality.
\end{abstract}

Keywords. solar observation device, horizon solar observations, Chankillo, solar cult, warrior cult

The group of structures known as the Thirteen Towers is found within Chankillo, a large ceremonial centre with ritual, administrative, and defensive attributes located in the coastal desert just outside the flood-plain of the southern branch of the CasmaSechín river basin, in the Ancash region of Peru (Fig. 1). Thirty-two ${ }^{14} \mathrm{C}$ dates from excavations in various parts of Chankillo were run mostly on remains of short-lived plants, in order to minimize the 'old-wood' problem, which is especially troubling on the coast of Peru (Fig. 2). Five of these samples (AA57020, AA57022-25) were obtained using dendrochronological principles from the outer rings of wooden lintels still plugged into the architecture at Chankillo. These five dates are a close approximation to the treecutting dates, and thus provide an excellent construction date for the site. All thirtytwo dates fall within the range 2350-2150 CalBP. Taking into account the spread of their probability distributions, Chankillo was occupied at approximately 400-100 CalBC, placing its construction, occupation and abandonment within the late Early Horizon period (500-200 BC) (Burger 2008).

Chankillo contains multiple structures, plazas, and courtyards, built out of shaped stone and mortar, spread over approximately $4 \mathrm{~km}^{2}$ of rock outcrops and sand ramps. Its best-known feature is a $300 \mathrm{~m}$-long hilltop structure, built in a defensive location, 


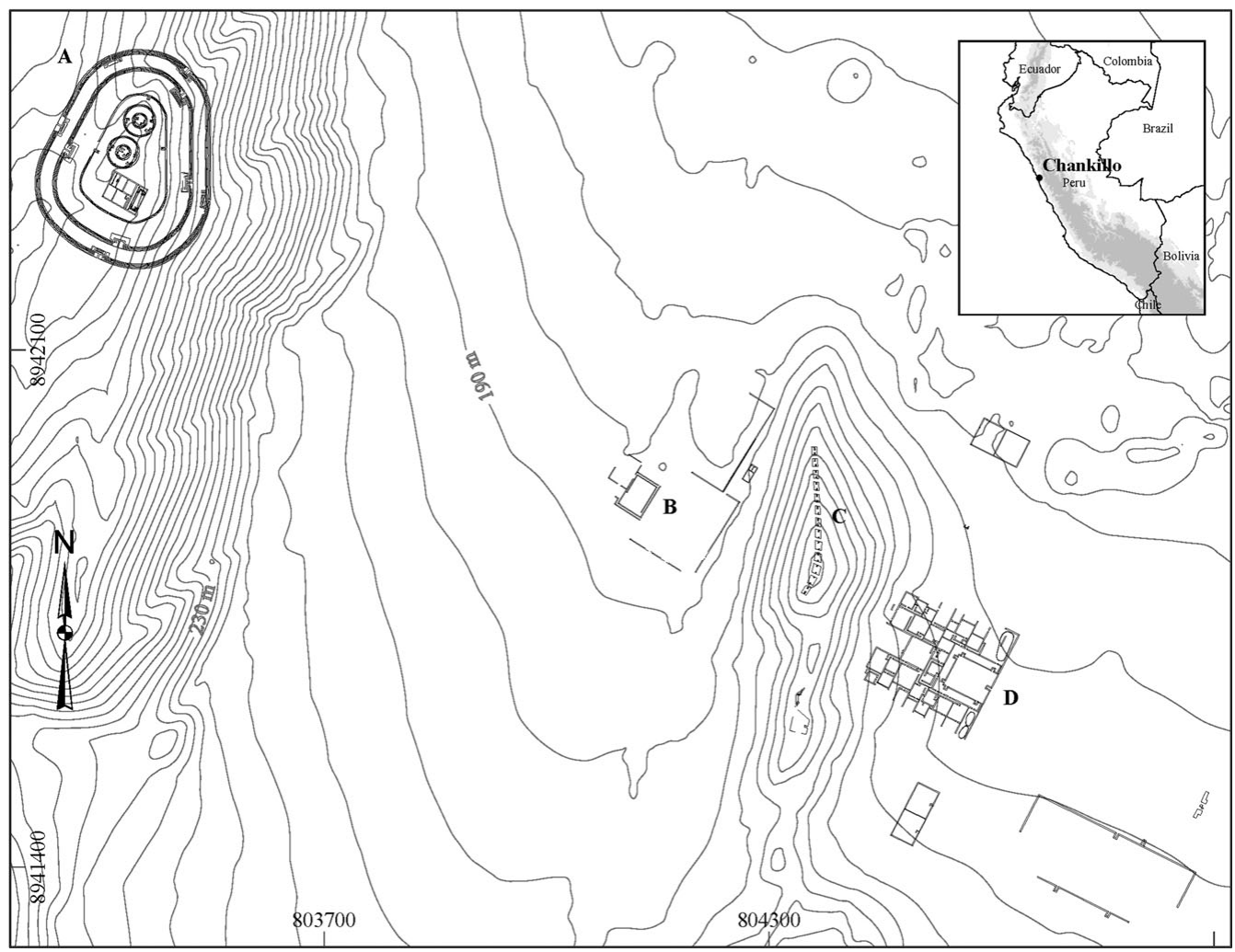

Figure 1. Archaeological map of the main building complexes at Chankillo, including $(A)$ the Fortified Temple, $(B)$ the Observation Building, $(C)$ the Thirteen Towers, and $(D)$ the administrative complex. Coordinates UTM, Zone 17S, WGS 1984.

heavily fortified with massive walls, restricted gates, etc. (Fig. 3(left)). The function of this massive structure has been subject to considerable debate in the archaeological literature, where it has been described as a fort, a redoubt, and a ceremonial setting for ritual combat. Recent research supports an alternative interpretation of this hilltop building as a 'fortified temple', set at a time when warfare was ideologically motivated, and the symbols and places of power were prime targets for attack and destruction (Ghezzi 2006; 2007).

East of the hilltop temple is found a civic-ceremonial area with buildings, plazas, courtyards, storage facilities, and the Thirteen Towers: a row of thirteen constructions placed along the ridge of a low hill approximately at the centre of the Chankillo site (Fig. $3($ right $)$ ). The Thirteen Towers are relatively well preserved; their corners have collapsed, yet enough survives to permit a description. They are stone-and-mortar elevated constructions, with summit access by inset staircases on their north and south sides. Their groundplan varies noticeably from rectangular to rhomboidal. They were plastered and may have been decorated. Their size $\left(75-125 \mathrm{~m}^{2}\right)$ and height $(2-6 \mathrm{~m})$ vary widely. The northernmost towers are much taller than the rest, apparently to compensate to some extent for the drop in elevation of the natural hill on which they were built. Nonetheless, they are regularly spaced: the gaps between the towers range only from 4.7 to $5.1 \mathrm{~m}$.

The towers were flat-topped, originally forming a smooth, 'false' horizon as viewed from the lower ground to the west or east. Despite the collapse of their corners, most of their summits are well enough preserved to permit their original heights to be determined 


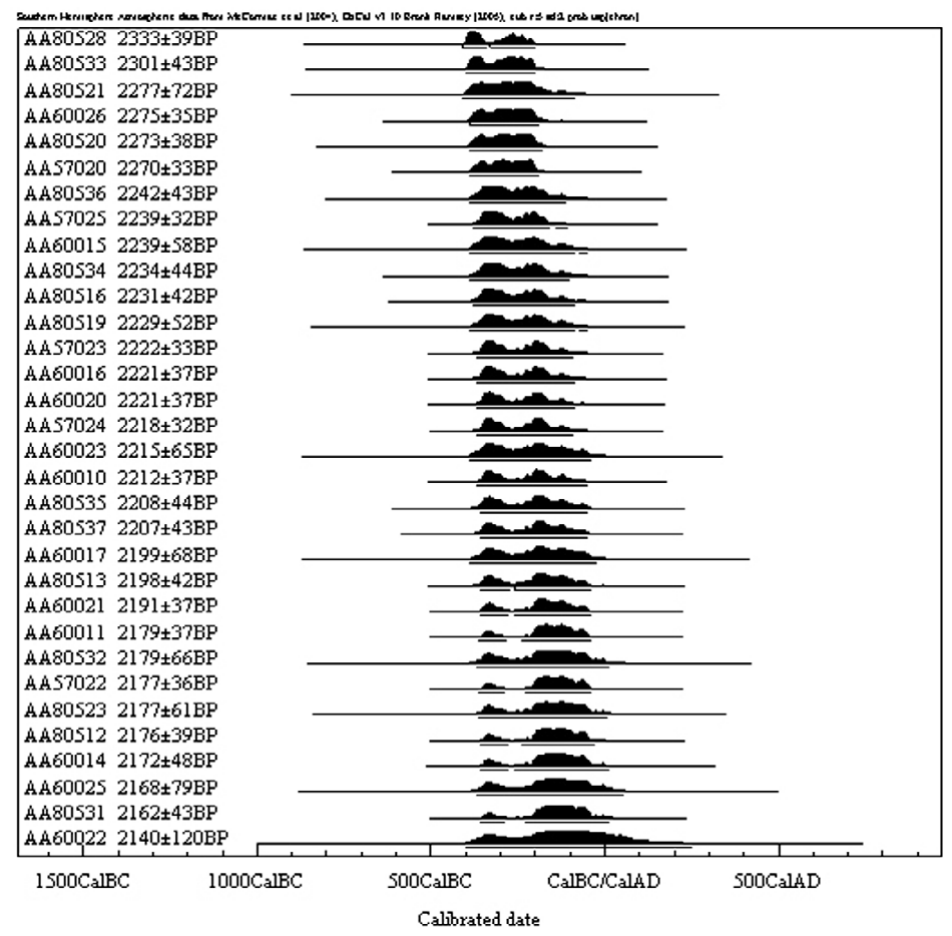

Figure 2. Calibrated BP date ranges for radiocarbon samples from Chankillo. For each sample, the first column represents the laboratory (NSF-Arizona AMS Laboratory) identification number. The shaded area refers to the probability distribution of possible intersection points with the calibration curve, and the horizontal line below it represents the 2 -sigma calibrated age range.
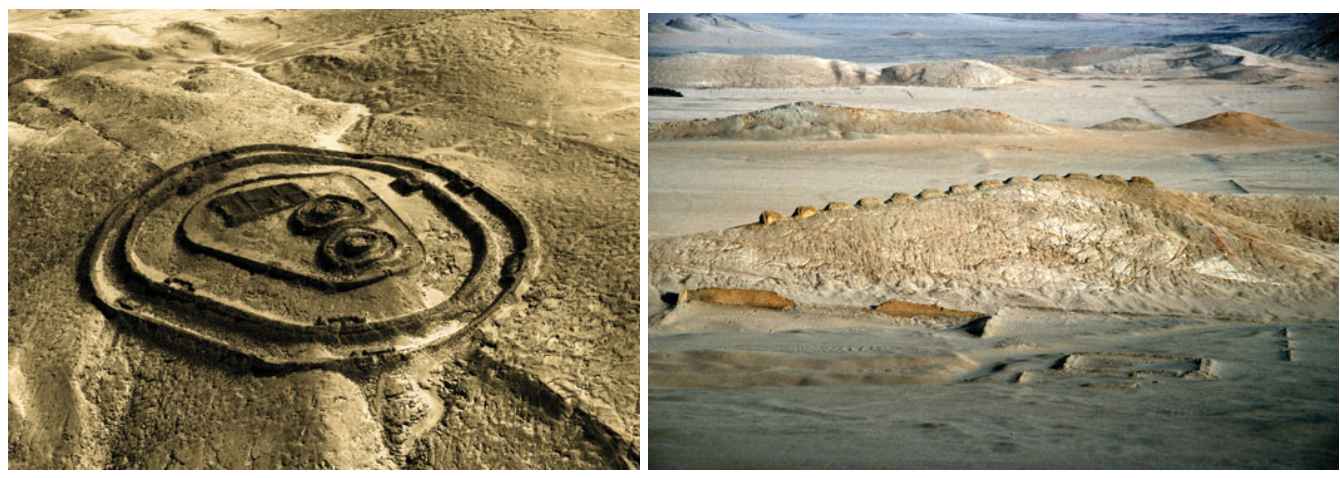

Figure 3. (Left): Aerial view of the fortified temple (Servicio Aerofotográfico Nacional, Peru). (Right): The Thirteen Towers of Chankillo, as viewed from the fortified temple.

accurately. No artefacts remain on the summits, yet the staircases strongly suggest that these surfaces were occupied at special times. The ascension to the tower summits may have been very important ritually, yet because their staircases are narrow $(1.3-1.5 \mathrm{~m}$ wide), and their length $(1.3-5.2 \mathrm{~m})$ and height $(2-6 \mathrm{~m})$ vary in proportion to the tower dimensions, several of them are too steep to climb. The staircases are generally aligned to the short axis of the towers; northern staircases are usually centred along the north side of the tower, while southern staircases are most often offset towards the east. The 
importance of the concept of duality has been amply discussed for the Central Andes (Millones \& Onuki 1993), and its manifestation in the dual staircases at the towers, as well as the double step-motif in sacred architectural elements (Ghezzi 2007) and pottery motifs (Ghezzi 2008; Ghezzi \& Ruggles 2008) at Chankillo reflect the great symbolic importance of the towers.

The line of towers runs broadly north-south, although towers 11-13 are twisted around towards the south-west (Fig. 4A). Also, Towers 11 and 12 cover the largest ground area. This may suggest that Tower 13 was intentionally 'hidden' from some eastern viewing positions. Yet the azimuths of the gaps between the towers, which vary progressively, north to south, from approximately $90^{\circ}-270^{\circ}$ to $120^{\circ}-300^{\circ}$, suggest something else: that the purpose of the notable variations in the orientation of the tower axes was to orient the gaps between the towers towards a pair of rectangular buildings within a walled enclosure directly to the west. The best preserved of these two buildings is $53.6 \mathrm{~m}$ long and $36.5 \mathrm{~m}$ wide, and it has several interior corridors, as well as an exterior one that runs $40 \mathrm{~m}$ along the southern side of the courtyard (Fig. 4B). This corridor connected a restricted doorway on the north-west side with an opening on the south-east side that was unobstructed and directly faced the towers $235 \mathrm{~m}$ away. However, the south-east doorway, unlike every other doorway at Chankillo, did not have the typical barholds, or small niches where a pin was firmly tied into the stone masonry and presumably used to attach a wooden door (Topic \& Topic 1997). In other words, it was a doorless opening. This corridor, then, was a unique construction that ran alongside the courtyard building but never led into it. Its sole purpose was, apparently, to channel movement from its restricted entryway to a doorless opening directly facing the towers.

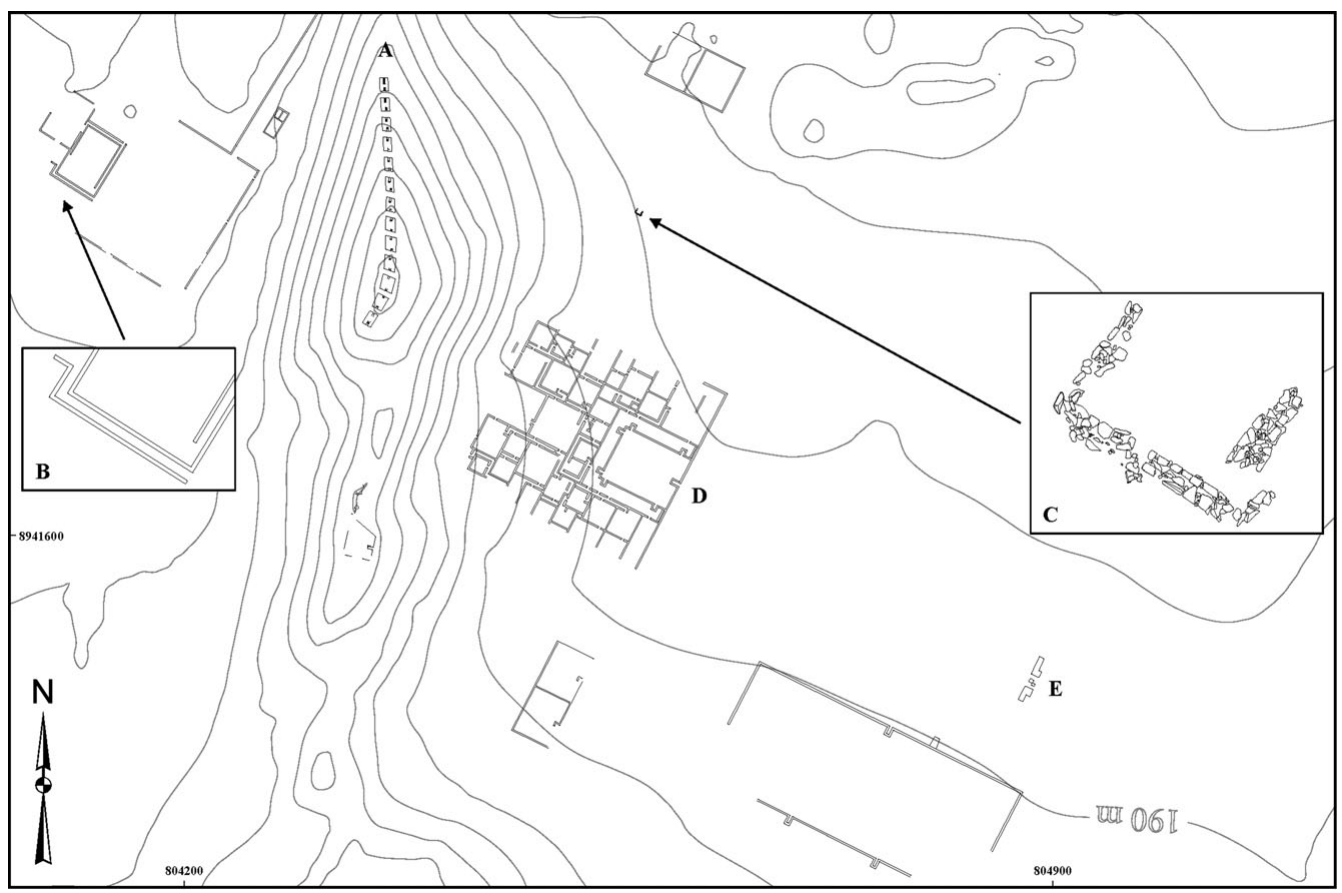

Figure 4. Plan of the Thirteen Towers and adjacent buildings: $(A)$ the Thirteen Towers; $(B)$ the external corridor and western observing point; $(C)$ the eastern observing point; $(D)$ the administrative complex; and $(E)$ unexcavated structure on the eastern end of the plaza. Coordinates UTM, Zone 17S, WGS 1984. 
Figure 5. The Thirteen Towers as viewed from $(A)$ the western observing point and $(B)$ the revised eastern observing point, annotated with the positions of sunrise/set at the solstices, 'temporal equinoxes' (cf. Ruggles 1997), and the dates of zenith and antizenith passage in around $300 \mathrm{BC}$. Results from 2010 Total Station survey.

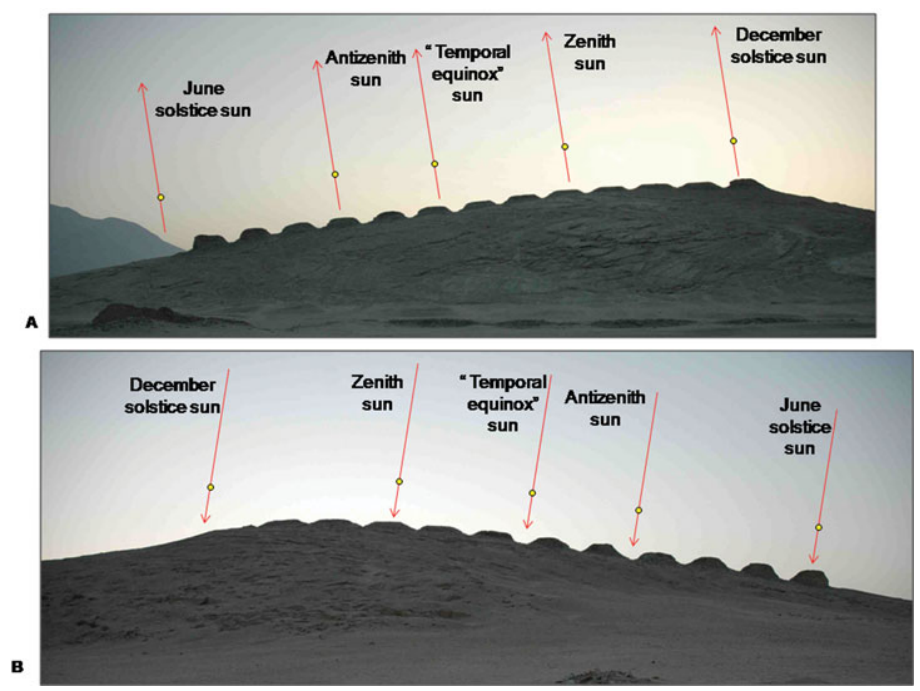

Considering the width of the corridor $(2.4 \mathrm{~m})$ and the original height of its walls $(2.2 \mathrm{~m})$, it is only by reaching the opening that the observer acquires an unobstructed view of the full row of towers. Archaeological excavations around the opening revealed that the corridor, like the rest of the building, was carefully constructed, plastered, and painted white. Offerings of pottery, shell, and lithics were found at floor level, suggesting that significant elements of ritual were involved in the process of passing through the corridor and standing at its end to observe the towers. Given the orientation, position and other unique features of the corridor, we hypothesized that it was a place to observe the towers, and termed its opening the 'western observing point'. In what follows, we refer to the building itself as the 'Observation Building' $†$

The Thirteen Towers form an artificial 'toothed' horizon, with relatively narrow gaps at regular intervals, as seen from the buildings and plazas below them, on either side. Thus, we hypothesized that there could be an eastern observing point as well. To the east of the towers is a large area $\left(1.4 \mathrm{~km}^{2}\right)$ with several buildings, including a large complex of interconnected rooms and patios, a large plaza $\left(0.16 \mathrm{~km}^{2}\right)$ and smaller buildings. In several places within the plaza were found offerings of ceramic panpipes and thorny oyster (Spondylus princeps sp.), while the middens near the plaza contained remains of serving vessels, ceramic panpipes, and maize. This area was probably a setting for large gatherings, where ritual feasts could take place according to a ceremonial calendar. A $25 \times 25 \mathrm{~m}$ archaeological excavation in an area that mirrors the position of the western observing point (similar easting, elevation, and distance from the towers) revealed the poorly-preserved foundations of a $6 \mathrm{~m}$-wide rectangular room that was not visible on the surface (Fig. 4C). When viewed from inside this building, the spread of the towers also forms an artificial horizon. We hypothesized that the restricted entrance to this structure (using the western observing point as an analogy), was the eastern observing point, but its exact position cannot be known with certainty.

Chankillo's Thirteen Towers appear to represent a native form of landscape timekeeping: as seen from the observing points to the east and west, they span the entire annual solar rising and setting arcs, giving not only direct indications of all four solstitial rising

$\dagger$ We thus avoid the terminology 'observatory', which has rekindled discussion as to whether the term may be a misleading one for an empirical solar observation device such as this; see p. 3. 
and setting points, but also the means to identify every other day in the year by observing sunrise or sunset against the intervening towers (Fig. 5).

A Total Station survey was undertaken in 2010 both to check our earlier results (Ghezzi \& Ruggles 2007), obtained by differential GPS, and to explore issues about what could be observed from points other than the 'observing points' (for example, by crowds gathered on critical dates in the plazas). The main conclusions were as follows:

- The results from the western observing point are fully corroborated. In addition, good weather conditions revealed that the centre of the sun rising at the June solstice $\left(\delta=+24.0^{\circ}\right)$ to the left of Tower 1 , corresponds not to an arbitrary point on the slopes of Cerro Mucho Malo but to the junction with a more distant 'cradle-shaped' hill behind it (Fig. 6A). This result lends important support to our previous argument (Ghezzi \& Ruggles 2007) that this natural hill may have been perceived as the leftmost 'tower' in this profile, and that besides the evident symmetry with the rest of the tower alignments, it may have been symbolically important that midwinter was the one time of year when the sun emerged between a natural hill and a human construction (Tower 1). In the same vein, an Inca 'fertility' offering of a female figurine inside a marine shell (Ghezzi 2008), carefully deposited in the centre of the first step of the northern staircase of Tower 1, highlights the relationship between this tower and June solstice harvest festivals, a relationship that was apparently recognized and honoured by the Inca almost two millennia later.

- Since the eastern observing point cannot be determined with certainty, new measurements were made from the approximate centre of the small building east of the towers (Fig. 4C). As viewed from this slightly corrected eastern observing position, the June solstice sun would have set squarely into the top of the rightmost tower, Tower 1 (Fig. 5B), mirroring the way in which, as viewed from the western observing position, the December solstice sun would have risen squarely out of the top of the rightmost tower, Tower 13 (Fig. 5A).

- As viewed from the only entrance to the large complex of interconnected rooms directly east of the towers (Fig. 4D), the southernmost tower (Tower 13) marks the setting of the June solstitial sun (Fig. 6B).

- As seen from the 'Observation Building', the Fortified Temple to the west also forms an artificial horizon. Directly opposite to the corridor containing the western observing point, there is a parallel west-facing corridor with, apparently, a NW opening towards the temple (Fig. 4). This dual arrangement embodies the principles of opposition/complementarity that characterize Andean dualism, thus making this new corridor a candidate for a west-facing observing point. From its possible NW opening, to be confirmed by excavations, the June solstice sun set into the gap immediately to the left of the Temple of the Pillars, the rectangular building within the hilltop temple, between its south wall and the inner defensive wall of the whole temple. The Temple of the Pillars was positioned so that the sun never (quite) set behind the building itself (Fig. 6C).

- The rectangular building abutting the NW side of the 'Observation Building' is oriented upon the top of the southern inner wall of the southern circular building within the Fortified Temple (Fig. 6D). The declination range of the top of the southern inner wall as viewed from the approximate centre of this rectangular building is $+28.0^{\circ} \leqslant \delta \leqslant$ $+28.3^{\circ}$. The fact that this is very close to the theoretical most northerly setting point of the moon (centre: $+28.0^{\circ}$ ) raises the possibility of a lunar association.

- From a small, unexcavated structure found on the eastern end of the large plaza (Fig. 4E), the gap between Towers 12 and 13 aligns with the single entrance to the Temple of the Pillars (Fig. 6E), perhaps the most sacred place in the Chankillo site (Ghezzi 2006). This yields a declination of $+28.0^{\circ}$, once again corresponding to the northernmost setting position of the moon (at 'major standstill'). 


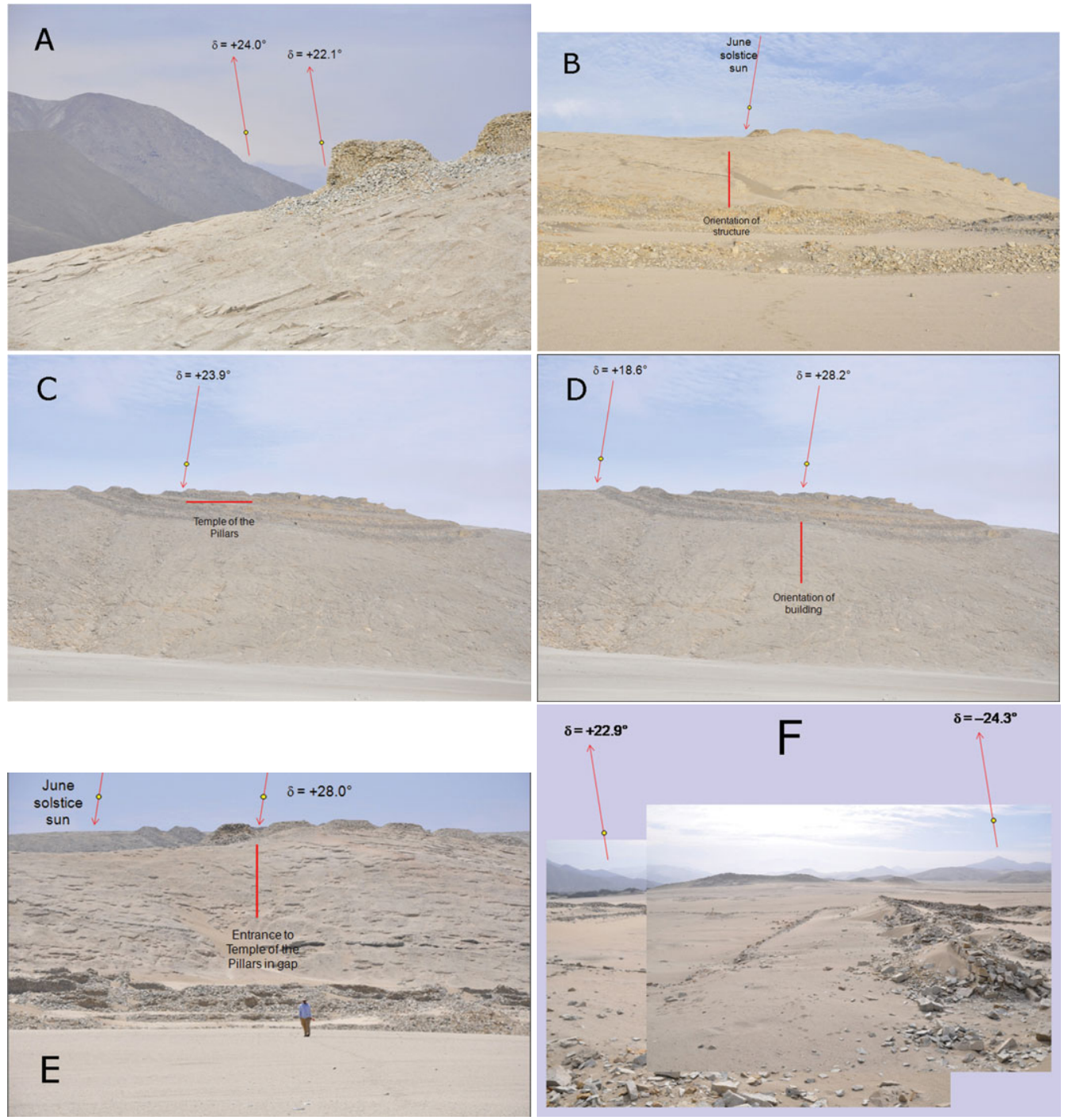

Figure 6. Results from the 2010 archaeoastronomical survey (see text).

Photos by Clive Ruggles.

- The natural horizon profile to the east of the site shows significant features close to the solstitial positions, and a distant stretch of mountainous horizon between them, suggesting that it may have provided a precursor and inspiration for the towers (Fig. 6F).

The archaeoastronomical interpretation of the Thirteen Towers and aligned structures raises several issues. One is whether, given the resemblance between the Thirteen Towers and the pillars of Cusco as horizon observation devices (Bauer \& Dearborn 1995), similar practices could have been common within the civilizations that developed in the Andes prior to the Inca. Is it possible to extrapolate aspects of the social and ritual context in which astronomical observations operated in imperial Cuzco to 4th-century-BC Chankillo?

Also, the artificial horizon created by these towers was broken at regular intervals by deep, narrow cuts formed by the gaps between them. When viewed from the western 
observing point, the sun rose for just one or two days in each gap. The even spacing of the gaps discounts the idea that they mark even intervals of time throughout the year, since the daily change in the sunrise position slows down towards the solstices (Ghezzi \& Ruggles 2007), but can the disposition of the towers nonetheless tell us something about the way the year was divided?

Given the clear defensive and civic-ceremonial nature of the site, another interesting question concerns the nature of the relationship between the calendar, as regulated by astronomical observations, and social, ritual, and military activities by the society that built Chankillo. It is obvious that such observations may have regulated a ritual calendar, but what about the possible relationship between astronomical events and warfare?

Finally, one could now develop various research questions concerning cosmology, exploring for instance the origins of solar, and possibly lunar, cults and the existence of possible beliefs in a solar origin of the elite.

However, in this paper we shall focus on placing the archaeoastronomical results in the context of the archaeological evidence from Chankillo.

Even where it is possible to recognize direct observations of the annual movement of the rising or setting sun along the horizon to regulate seasonal events such as religious festivals, or for maintaining a seasonal calendar, evaluating the nature of those observations, and the social and ritual context within which they operated, is not simple. A starting point is to realize that horizon astronomy can be practiced using simpler means than the markers and observing points at Chankillo. There are many examples of the practice of horizon astronomy among traditional societies using a natural horizon with distinctive elements such as peaks, slopes, rocks, etc. (Ruggles 2005). At Chankillo, on the other hand, the elements that compose the astronomical alignments are formally defined by highly visible, ad-hoc constructions on a monumental scale that occupy a central position in what was the most important public space for this society. The amount by which the symbolism, form, and context of the towers exceed what is required for their most basic function as horizon markers casts doubt that their only purpose would have been practical, simply to regulate agriculture, fishing, and other seasonal activities. Quite to the contrary, it is evident that their design and construction involved different principles and motivations - ideological, ritual, social, political, and so on. Among the Maya, for instance, the recognition and prediction of celestial cycles, ultimately for the purposes of prognostication, is known from written evidence to have gone far beyond the obvious needs of regulating annual cycles of activity in accordance with the seasonal changes of nature (Aveni 1992).

What, then, is the social and ritual setting in which such astronomical observations took place at Chankillo? To answer this, it is necessary to contextualize the astronomical alignments with the archaeological evidence (Ghezzi 2006; 2007; 2008). There are indications that the society that built Chankillo was on a path towards increasing political centralization and social differentiation. For example, the site layout reflects a strong degree of social differentiation in its design, with a large plaza bearing evidence of massive public activities, while access was tightly controlled to buildings such as the Fortified Temple and the Observation Building, and thus to the rituals practiced in these places.

Another indication is the abundant surficial evidence for ritual banquets (Ghezzi 2004). Throughout the plaza there were offerings of panpipes and thorny oyster. Surrounding the plaza were found many middens, filled with the remains of utilitarian vessels, panpipes and corn. Also, to the rear of the great complex of interconnected rooms east of the towers there are facilities for the preparation and storage of drinks - probably chicha (corn beer), to judge by the abundant maize remains. Thus, the plaza would have held great public feasts in which food and drink were consumed, accompanied by music, dancing and other 
ritual practices. During the festivities, a large number of pilgrims would have gathered from a vast region surrounding Chankillo. The festivities would have been scheduled and organized by means of a ritual calendar, defined by the systematic observation of the seasonal passage of the sun from the Observation Building. Notable astronomical events, visible not only from the observing points by a few, but by many from the plazas - such as June solstice sunset seen over Tower 13 from the front courtyard of the complex of interconnected rooms - would have been central dates in this ceremonial calendar. The people in charge of this building would have played an important 'administrative' role in the preparation, storage, and redistribution of food, drink and other goods during these festivities, thus acting as organizers of ceremonies while controlling the participating masses.

The redistribution of goods and foodstuffs in a ritual context, to create mutual bonds of reciprocity, provide funds and/or labour for projects, establish alliances, exchange marriage partners, etc., is one of the strategies universally practiced by the leaders of a society to obtain the economic, social and political advantages that consolidate and reproduce the inequalities of wealth and status upon which they base their power (Bray 2003; Hayden 2001). Thus, at Chankillo, the individuals with access to sacred spaces, and in control of astronomical knowledge and the calendar, would have been the instigators and great benefactors of public banquets scheduled by the movement of the sun. These leaders would have possessed the ability to manipulate time, ideology, calendrical rituals and the solar cult amidst an impressive scenario that integrated society while the same time accentuating its growing inequality. They may even have claimed a special relationship with the Sun, as the Inca kings did almost two thousand years later.

From this perspective, it is interesting to consider the images of warriors from Chankillo (Fig. 7). The archaeological excavations have recovered a collection of ceramic figurines representing pairs of warriors engaged in duels (Ghezzi 2006; 2007; 2008). They bear specialized weaponry - mainly spear-throwers and darts, but also maces and spears - that is appropriate for the attack and defence of a fortification, besides being important in handto-hand combat, and in the prestige it confers. They also bear shields and other forms of body protection, indicating the importance of the physical integrity of the warrior during battle. Besides the military and social prestige provided by skill and experience in combat, warriors used a variety of headdresses - shirts, and capes, as well nose, neck and torso ornaments, probably made of metal - that reflected their elevated social status.
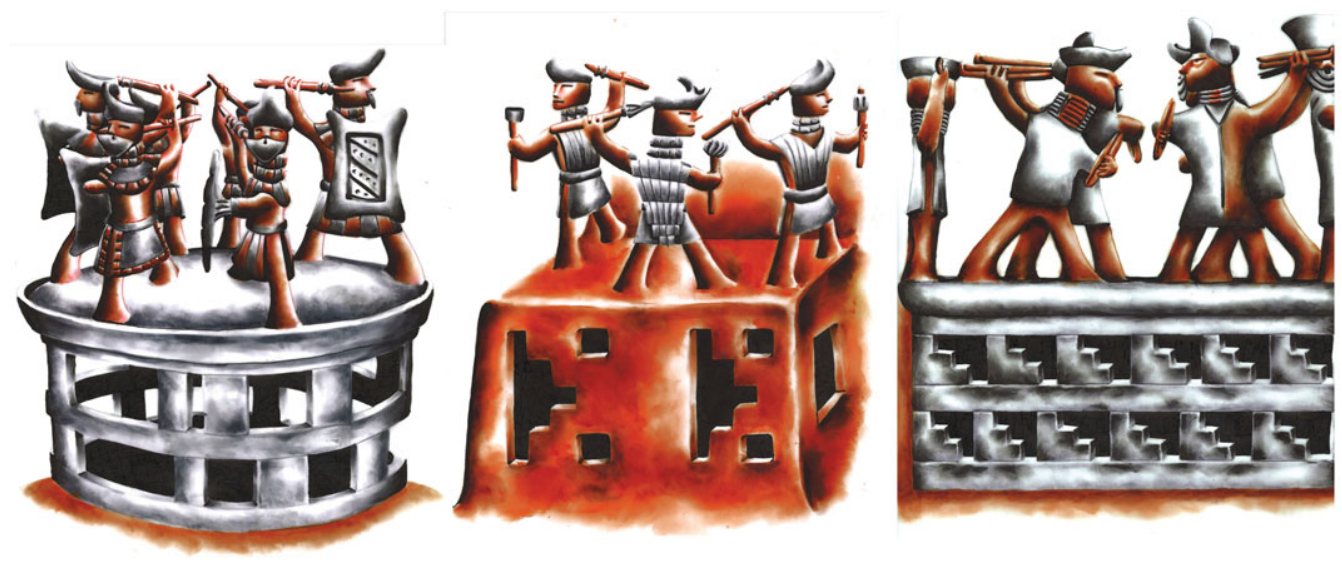

Figure 7. An artist's reconstruction of ceramic vessels decorated with figurines representing pairs of warriors engaged in duels atop public buildings. 
These high-status symbols, as well as the preoccupation with the physical integrity of the warrior in combat, suggest the rise of an elite class of warrior leaders. Thus, a paramount role in the solar cult and related cosmological beliefs, the orchestration of ceremonial banquets, the redistribution of goods, and of course excellence in combat, may all have been attributes that lent legitimacy and authority to the elite in Chankillo, as was the case among the Inca. The Observation Building and the Thirteen Towers, then, were not solely the expression of advanced astronomical knowledge, nor simply an empirical instrument for solar observations, but a place where the ceremonial calendar was regulated and re-created, and where the established social hierarchies were reproduced.

\section{References}

Aveni, A. F. (ed.) 1992, The Sky in Mayan Literature, Oxford University Press, New York.

Bauer, B. S. \& Dearborn, D. S. P. 1995, Astronomy and Empire in the Ancient Andes: the Cultural Origins of Inca Sky Watching, University of Texas Press, Austin.

Bray, T. L. (ed.) 2003, The Archaeology and Politics of Food and Feasting in Early States and Empires, Kluwer Academic/Plenum, New York.

Burger, R. L. 2008, Chavín de Huántar and its sphere of influence. In H. Silverman \& W. H. Isbell (eds), The Handbook of South American Archaeology, Springer, New York, pp. 681-703.

Ghezzi, I. 2004, Proyecto Arqueologico Chankillo: Informe de la Temporada 2003, Instituto Nacional de Cultura, Lima.

Ghezzi, I. 2006, Religious warfare at Chankillo. In W. H. Isbell \& H. Silverman (eds), Andean Archaeology III, Springer, New York, pp. 67-84.

Ghezzi, I. 2007, La naturaleza de la guerra prehispánica temprana: la perspectiva desde Chankillo. Revista Andina 44, 199-225.

Ghezzi, I. 2008, Los primeros tambores de la guerra: combate y ritual en la costa norte después del ocaso de Chavín. In K. Makowski (ed.), Los Señorios del Reino de la Luna, Banco de Crédito del Perú, Lima, pp. 39-53.

Ghezzi, I. \& Ruggles, C. L. N. 2007, Chankillo: a 2300-year-old solar observatory in coastal Peru. Science 315, 1239-1243.

Ghezzi, I. \& Ruggles, C. L. N. 2008, Las trece torres de Chankillo: arqueoastronomía y organización social en el primer observatorio solar de América. Boletín de Arqueología PUCP 10, $215-236$.

Hayden, B. D. 2001, Richman, poorman, beggarman, chief: the dynamics of social inequality. In G. M. Feinman \& T. D. Price (eds), Archaeology at the Millennium: a Sourcebook, Kluwer Academic/Plenum Publishers, New York, pp. 231-272.

Millones, L. \& Onuki, Y. 1993, El Mundo Ceremonial Andino, Senri Ethnological Studies no. 37, Museo Nacional de Etnología, Osaka.

Ruggles, C. L. N. 1997, Whose equinox? Archaeoastronomy no. 22 (suppl. to Journal for the History of Astronomy 28), S45-S50.

Ruggles, C. L. N. 2005, Ancient Astronomy: an Encyclopedia of Cosmologies and Myth, ABCCLIO, Santa Barbara.

Topic, J. R. \& Topic, T. L. 1997, Hacia una comprensión conceptual de la guerra andina. In R. Varon Gabai \& J. Flores Espinoza (eds), Arqueología, Antropología e Historia en los Andes: Homenaje a María Rostworowski, transl. J. Flores Espinoza, Historia Andina vol. 21, Instituto de Estudios Peruanos, Lima, pp. 567-590. 